This work is licensed under a Creative Commons Attribution 4.0 International License.

Ovaj rad dostupan je za upotrebu pod međunarodnom licencom Creative Commons Attribution 4.0.

https://doi.org/10.31820/f.31.1.6

Jasna Vince

\title{
IMENSKI PREDIKAT S NEPRELAZNIM GLAGOLIMA U HRVATSKOGLAGOLJSKIM TEKSTOVIMA
}

dr. sc. Jasna Vince, jvince@stin.hr, Zagreb

izvorni znanstveni članak

UDK 811.163.1'367.332.7

rukopis primljen: 30. travnja 2019.; prihvaćen za tisak: 31. svibnja 2019.

Rad je posvećen neprelaznim glagolima i imenskim skupinama koji čine imenski predikat u hrvatskom crkvenoslavenskom jeziku. U ulozi „čiste” spone, lišene leksičkoga značenja pojavljuju se samo prezentski oblici glagola biti tvoreni od *es-osnove. Finitni oblici potekli iz osnove *bheu- postavljaju događaju vremenski okvir. Raščlanjuje se nadalje i velika skupina polusponskih glagola koji oblikuju značenja 'ostati', 'biti stvoren', 'postati, 'praviti se, pretvarati se', 'činiti se, izgledati' i 'zvati se'. Autorica upozorava na utjecaj grčkih i latinskih predložaka kao i govornoga jezika na sintaktičke sklopove hrvatskoga crkvenoslavenskog jezika.

Ključne riječi: hrvatski crkvenoslavenski jezik; imenski predikat; sponski i polusponski glagoli; predikatno ime; latinski i grčki predložak

\section{Uvod}

Otkako je krajem prošloga stoljeća uvelike poraslo zanimanje za sintaksu hrvatskoga crkvenoslavenskoga jezika, redovito se ističe da je to najslabije istražena jezična razina. Slijedi obično primjedba kako se u novije doba stanje popravlja, a popis radova kojima se ona potkrepljuje svakim je danom sve dulji. Knjige, studije i članci posvećeni su uže ili šire postavljenim 
sintaktičkim pitanjima, a zanimanje autora usmjereno je prema pojedinim pisanim spomenicima ili njihovim skupinama, ali i prema različitim žanrovima i različitim razdobljima hrvatskoga glagoljaštva. Sazrelo je već i vrijeme za pregled dosadašnjih rezultata. Milan Mihaljević predstavio je nedavno četiri naraštaja proučavatelja sintakse hrvatskoga crkvenoslavenskoga jezika i njihove radove (Mihaljević, Milan 2018). Skupu posvećenu povijesnoj sintaksi ${ }^{1}$ ovaj rad pripada ponajprije zato što je u njemu riječ o najstarijem hrvatskom književnom jeziku, a uočene sintaktičke mijene nisu samo plod unutarnjega razvoja, nego su objašnjive i različitim inojezičnim utjecajima. ${ }^{2}$

Ima sintaktičkih pitanja kojih su se proučavatelji hrvatskoga glagolizma i dosad doticali u sklopu svojih tekstoloških ili jezičnih istraživanja, ali nikada nisu postali glavnim predmetom raščlambe. Jednoj od takvih tema posvećen je ovaj rad. ${ }^{3} \mathrm{U}$ njemu ćemo prikazati rečenice s imenskim predikatom u hrvatskom crkvenoslavenskom jeziku služeći se spoznajama i pojmovljem tradicionalne gramatike. Usredotočit ćemo se samo na rečenice s neprelaznim glagolima, koji „označuju da se što pripisuje subjektu” (Silić, Pranjković 2005: 291). O njima možemo pročitati i ovo: „Ako se subjektu pripisuje neka osobina, stanje ili funkcija (a to se izriče imenom, tj. imenicom, zamjenicom, pridjevom ili brojem), veza između ta dva pojma izriče se glagolima biti, postati, ostati, činiti se, zvati se (...) i sličnim. Takav se predikat naziva imenski predikat, glagol u njemu je kopula (spona), a imenski dio predikata zove se predikatno ime" (Pavešić, Vince 1971: 427). U nekim je radovima naziv spona ograničen na glagol biti, a ostali nabrojeni glagoli semikopulativni su ili polusponski (Silić, Pranjković 2005: 290-291). Za razliku od puke spone, glagoli ostati, činiti se, zvati i sl. opremljeni su i leksičkim značenjima prema kojima su u ovom radu i razvrstani u skupine. S druge strane, oni kao i spona

1 Upravo je povijesna sintaksa - uz povijesnu leksikografiju te pravopisna i srodna pitanja - područje na kojem se spoznaje o „unutarnjoj povijesti jezika” plodonosno isprepleću s dostignućima do kojih su došli istraživači „vanjske povijesti jezika”, primjerice Vince (1978).

2 Nadovezujući se na prosudbe ranijih autora, Diana Stolac i Anastazija Vlastelić iznose tri tumačenja uloge povijesne sintakse: „a) proučava sintaksu u ranijim razdobljima jezičnoga razvoja, b) opisuje sintaktičke mijene u različitim fazama jezičnoga razvoja i c) odgovara na pitanje zašto je uopće došlo do određene promjene na razini sintakse" (Stolac, Vlastelić 2017: 642).

3 Građa za istraživanje ista je ona na kojoj se temelji Rječnik crkvenoslavenskoga jezika hrvatske redakcije (usp. RCJHR 2000: XXXI - XXXVI), obogaćena podatcima iz dostupnih preslika i izdanja pojedinih tekstova te iz radova proučavatelja jezika hrvatskih glagoljaša. 
biti zahtijevaju nadopunu koju donosi predikatno ime. Stoga se o njima govori kao o nesamostalnim glagolima (Florschütz 1940: 129). U gramatici se za dopune takvim glagolima uvriježio i naziv proširak (Peti 1979), koji valja strogu lučiti od predikatnoga proširka, koji nije obavezan (Birtić, Brač 2016: 313). Dioba predikatnih imena zasniva se na njihovim formalnim obilježjima koja odražavaju i razlike u značenju.

\section{Glagoli biti i bivati}

Prototipni su imenski predikati oni u kojima je spona glagol biti. U primjerima (1) i (2) sponski glagol popraćen je ostalim dvjema svojim ulogama - punoznačnoga i pomoćnoga glagola. U svim je potvrdama glagol biti u prezentu. Prvi je primjer zavisno složena rečenica u kojoj spona u glavnoj i punoznačni glagol biti kao predikat odnosne rečenice glase jednako. Prvi ostvaraj glagola biti u (2) pomoćni je glagol u gradbi perfekta, dok istozvučno esi u Brevijaru Vida Omišljanina spaja subjekt s participom prezenta aktiva I. kao predikatom.

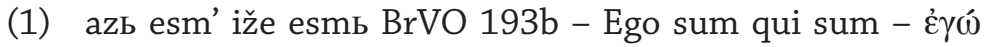

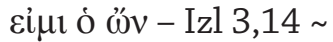

(2) ti stvorilb esi vsa $\mathrm{BrN}_{2} 134 \mathrm{~b}$ - ti esi sbzdavbi vsьčbskaě

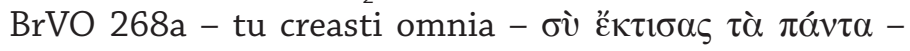
Otk 4,11

Iz Kožičićeve inačice primjera (3) razvidno je da spona može ostati neizrečena. Tu autor slijedi latinski predložak. ${ }^{4}$ Elipsa je poznata i grčkim biblijskim tekstovima odakle je posredno, preko starijih (staro)crkvenoslavenskih predložaka dospjela i u prijepise hrvatskih glagoljaša. Takvi su primjeri rjeđi jer je u prijevodima s grčkoga na starocrkvenoslavenski često

4 Istražujući utjecaj latinskoga i govornoga hrvatskoga jezika na Kožičićeve prevoditeljske postupke zamjetne na sintaksi njegova Misala hruackoga, autori Eterović i Vela (2013) među latinizmima opisuju i elipsu spone (uz praesens historicum, upotrebu kondicionala, upotrebu infinitiva, relativno vezivanje i intonacijska pitanja). Zaključuju kako je elipsa spone u Kožičićevu Misalu hruackom, po uzoru na latinski predložak, posve uobičajena i česta, čime se on razlikuje od ostalih tiskanih misala, Prvotiska misala, Senjskoga misala i Misala Pavla Modrušanina. Autori su ipak zabilježili sponu u sva četiri tiskana misala tamo gdje je u latinskome elipsa. Navode čak i primjer u kojem je samo u Misalu hruackom upotrijebljena spona, a u latinskome i u uspoređenim tiskanim misalima ona je izostala. (Eterović, Vela 2013: 122). 
uspostavljena spona koja u izvorniku manjka (Večerka 1996: 141). Brevijar Vida Omišljanina (2) čuva tako nastalu sponu uz particip preterita aktiva. Elipsa se u svim nabrojenim idiomima, grčkom, latinskom i (staro)crkvenoslavenskom obično opisuje kao hebrejizam, ${ }^{5}$ a ima i mišljenja kako je to iskonska praindoevropska, pa onda i praslavenska crta koja je pod stranim utjecajem samo učvršćena. ${ }^{6}$

(3) az' es(a)mь g(ospod)ь MHrv 54a - az g(ospod)ь MKož

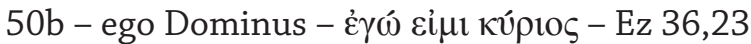

Prezentski oblici glagola biti potvrđeni u primjeru (5): budu, budetb esi supletivno su povezani, što upućuje na njihovo različito postanje. ${ }^{7}$ Razlika između trajnog i trenutnog prezenta očituje se i u tome što se uz potonji predikatno ime osim nominativom (4) može izraziti i s pomoću prijedložnog izraza $v b+$ akuzativ (5). On se tumači kao hebrejizam posredovan grčkim ${ }^{8}$, a iz grčkoga ga je, kako se vidi, preuzeo i latinski. Razlučivanje svevremenskoga 'jesam' i budućega 'bit ću' i 'bit će' (5) ostvareno uz pomoć supletivnih oblika prezenta glagola biti time je dodatno poduprto. Iz samoga glagolskoga oblika nemoguće je međutim iščitati je li riječ o durativnom značenju ili o inkoativnom, koje se parafrazira kao 'postat ću'.

(4) i budu vam' ot(a)cb i vi budete mně s(i)n(o)ve i deĉeri

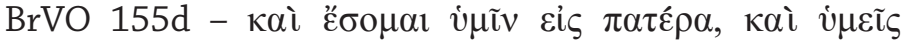

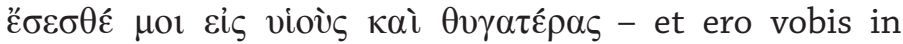
patrem et eritis mihi in filios et filias - 2Kor 6,18

(5) s(i)nь moi esi ti .. az' v(a)mb budu vb o(ta)сь i ta budetb

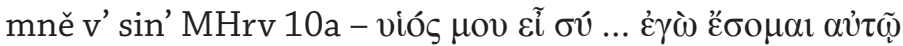

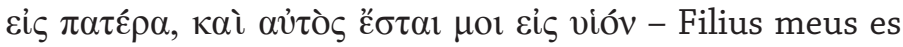
tu ... ego ero illi in Patrem et ipse erit mihi in Filium Heb 1,5

5 Podrobnije u Eterović, Vela (2013: 122).

6 Usp. o tome Damjanović (2005: 171).

7 „Kao što je glagol *es- u mnogim rečenicam degradiran na kopulu, tako su u pojedinim ie. jezicima i drugi neki glagoli. Tako se okreće u puku kopulu i glagol *bheu-, slav. byti, kojemu je prvo značenje upravo 'rasti, postajati' i koji se supletivno veže s glagolom *es-" (Ivšić 1970: 280).

8 Usp. HCSJ (2014: 362). 
Oblicima glagola biti u (4), (5) i (6), poteklima iz osnove *by- < *bheu-, zajedničko je upućivanje na događaj koji se tek očekuje ili priziva (ili se ne očekuje i ne priželjkuje), drugim riječima na promjenu. Imenica kao predikatno ime u takvim se okolnostima može pojaviti i u instrumentalu, kao u primjeru s imperativom budi iz Petrisova zbornika (6) ${ }^{9}$. I dok je hebrejizam $v b+$ akuzativ u hrvatskom crkvenoslavenskom jeziku čvrsto ukorijenjen (5), instrumental je kao novija pojava kako na našem tlu tako i uopće u slavenskim jezicima u doba koje promatramo još posve rijedak. Nastao je pod utjecajem živoga govornoga jezika.

(6) ne budi mědom' da tě ne požru ni budi čeměrom' da tě ne ispljuju CPet 99v

Većina potvrda potječe iz novoprevedenih tekstova, uglavnom iz novijih zbornika. ${ }^{10}$ Svi su instrumentali imenički, nikada pridjevski. To je tek jedan od čimbenika koji utječe na odabir instrumentala u predikativu. ${ }^{11}$

Glagolski oblik bih' u dvjema vremenskim rečenicama u prvoj inačici primjera (7), preuzetoj iz Vatikanskog misala Illirico 4, koji može stajati kako za imperfekt tako i za aorist, ${ }^{12}$ otkriva da je riječ o zbivanju u prošlosti, ali nam ništa ne govori o njegovu trajanju. Stanje je jednako onomu iz primjera (5), samo što je tamo pogled bio uprt u budućnost, a tu u prošlost. Tek se iz

${ }^{9}$ Kao i glavnina primjera s instrumentalom i ovaj je preuzet iz HCSJ (2014: 337).

10 Stariji i noviji zbornici međusobno se više razlikuju po zastupljenosti elemenata narodnoga govora nego liturgijski kodeksi. „Do polovice 14. st. crkvenoslavenski je imao ulogu književnoga jezika kojim su pisana i liturgijska i neliturgijska književna djela" (HCSJ 2014: 19).

$11 \mathrm{Na}$ smjenjivanje nominativa i instrumentala u starocrkvenoslavenskom jeziku već su davno upozorili češki, ali i drugi slavisti; usp. Bauerová (1963), Večerka (1993). O hrvatskom crkvenoslavenskom u usporedbi sa staročakavskim izvješćuje Vince Marinac (2001). U novije doba Ivana Brač prikazala je rasprostranjenost instrumentala u kopulativnim rečenicama širom slavenskoga svijeta s posebnim naglaskom na suvremeni hrvatski jezik. Istražila je i ograničenja povezana s tom pojavom koja se sažeto mogu opisati kao „pripisivanje subjektu kakve uloge ili svojstva koje nije trajno povezano s njim i neodvojivo od njega" (Brač 2017: 41). U slučaju predikativnoga instrumentala u hrvatskoglagoljskim tekstovima to objašnjava njegovo upućivanje na prošlost ili budućnost, a ne na sadašnjost i svevremenost. Nije slučajno što je u svim rijetkim (staro)crkvenoslavenskim primjerima instrumental potvrđen uz osnovu *bheu-, nikada uz ${ }^{*} e{ }^{-}$.

12 Stezanja koja su zahvatila oblike imperfekta počela su ugrožavati razlikovanje imperfekta i aorista već u starocrkvenoslavenskom jeziku (HCSJ 2014: 243). Na našem tlu neutralizaciji je pridonijela i ikavizacija jata. 
glagolskih oblika u glavnim rečenicama, imperfekta g(lago)lah' i aorista otvr'goh' zaključuje kako se tu ne pripovijeda o prošlosti u kojoj se muževno doba nastavlja na dječačko i dalje traje: *'kad sam bio dijete - kad sam bio odrastao čovjek', nego je razdoblje dječaštva u prošlosti prekinuto trenutkom odrastanja: 'kad sam bio dijete - kad sam postao odrastao čovjek'. U svim ostalim potvrdama, grčkoj, latinskoj, pa i u onoj iz usporednoga hrvatskoglagoljskoga Kožičićeva Misala hruackog obavijest je nedvosmisleno prenesena suprotstavljanjem dvaju glagola: běhb - stvorenb běhb, essem - factus sum,

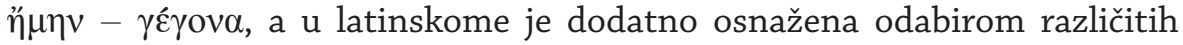
veznika, cum - quando. ${ }^{13}$

(7) egda bih' mladěnc' g(lago)lah' ěko mladěnc' ... egda že bih' mužb otvr'goh' ml(a)d(ě)nčkaě $\mathrm{MVat}_{4}$ 23d - běhь ...

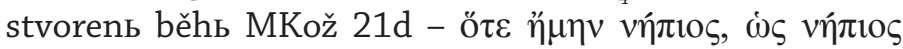

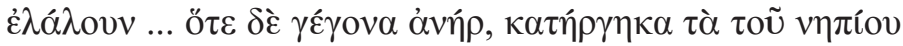
- cum essem parvulus loquebar ut parvulus ... quando factus sum vir evacuavi quae erant parvuli - 1Kor 13,11

I glagol bivati rabi se u hrvatskom crkvenoslavenskom jeziku trojako: kao punoznačni glagol 'bivati, događati se' (8), kao pomoćni glagol za tvorbu pasiva (9), pri čemu se smjenjuje s glagolom biti i kao spona (10) i (11). U primjeru (10) značenje glagola bivati je durativno, a u (11) iterativno 'postajati'.

(8) rukami že ap(usto)lъskami znameniě ï čudesa bъivahu vъ

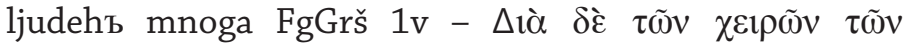

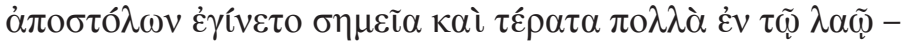
per manus autem apostolorum fiebant signa et prodigia multa in plebe - Dj 5,12

(9) g(ospod)b is(us)b v noĉ́ v njuže prědan' bivaše ... prělomi

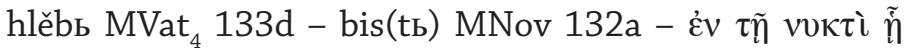
$\pi \alpha \rho \varepsilon \delta i ́ \delta \varepsilon \tau o$ - in qua nocte tradebatur - 1 Kor 11,23

\footnotetext{
13 Dva najstarija hrvatska latinička lekcionara, onaj Bernardina Splićanina i Ranjinin drže se kao i Kožičić latinskoga predloška, samo što umjesto glagola stvoriti rabe glagol učiniti u dvojakom pasivu (bih učinen i učinih se): Dokle bih mal̦acat ... kada jure bih učińen muž odnosno Kada bjeh mlad ... Kada ve istinom učinih se muž. Bernardin, kako se vidi, rabi i dva različita vremenska veznika (dokle / kada). Usp. Vince Marinac (2001: 286-288).
} 
(10) molju že vas' podobni mi bivaite BrVO 105a - $\mu \mu \eta \tau \alpha i ́$

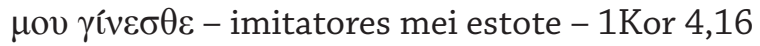

(11) eliko aĉe prikasahu se zdravi bivahu MVat 4 29a - et

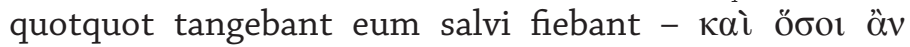

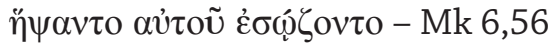

\section{Glagol stvoriti}

U ovom ćemo odjeljku ogledati usporedne rečenice s glagolima biti i stvoriti u značenju 'postati'. Ali prije toga valja primijetiti dvoje. Prvo, biti i stvorenb biti međusobno su zamjenjivi i kao punoznačni (jednovalentni) glagoli u značenju 'nastati', što pokazuju brojni primjeri, među njima i (12). Izraz stvorenb estb u različitim licima i brojevima ali i rodovima ropski je prenesen iz latinskoga izraza factus est, koji je i sam primjer supletivnosti, pri čemu su se oblici glagola sa značenjem 'učiniti' premetnuli u značenje 'postati. ${ }^{14}$ Slično se tomu i grčko $\gamma$ í $\gamma v o \mu \alpha l$ 'postati' etimološki vezuje uz $\gamma \varepsilon v \alpha \omega$ 'roditi. ${ }^{15}$

(12) i ot šes'toe godine t'me stvorene biše po v'sei z(e)mli CPar

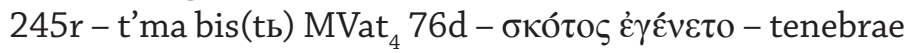
factae sunt - Mt 27,45

Drugo, oblike stvoren' bist', stvorena est' itd. nalazimo i kao prave pasivne parnjake aktivnima:

(13) tak'meni edinake i kras'ni stvori e $\mathrm{BrN}_{2} 94 \mathrm{c}$ - takmeni edinaki krasni stvoreni sutb BrVO 200a - eos pariles aequales decorasque fecit

Svijest o pokretaču radnje u tom je primjeru živo prisutna ne samo u aktivnoj rečenici iz II. novljanskog brevijara s objektom i proširkom u akuzativu, nego po uzoru na nju i u pasivnoj, potvrđenoj u Brevijaru Vida Omišljanina, u kojoj je objekt promaknut u subjekt u nominativu (doduše, neizrečen), a proširak / predikatno ime s njime je sročan. U tom slučaju stvoreni sutb nije zamjenjivo glagolom biti. Kada se veza s uzročnikom, koji je u pasivnim rečenicama obično ionako malo važan, posve dokine, otvara

14 Usp. facio, feci, factum, facere i fio, factus sum, fieri (Divković 1900: 396, 417).

15 Usp. Senc (1910: 169). 
se put prema značenju 'postati'. O tome svjedoče stvorěnb esi zabilježeno u Lobkowiczovu psaltiru na mjestu na kojem u Pariškom psaltiru stoji b(i)si (14), zatim stvorena bista u Pariškom zborniku prema Kožičićevu prijevodu bista (15) kao i Kožičićevo stvorenb běhb za drugo bih' u Vatikanskom Illirico 4 (7) i niz drugih primjera. ${ }^{16}$

(14) g(ospod)i pribežiĉe stvorěnь esi namb PsLob 54v - b(i)si PsPar 48v

(15) i bista priětela irudb i pilatb ... nepriětela bo běhota prěe MKož $74 b^{17}$ - stvorena bista ... bihota CPar 258v -

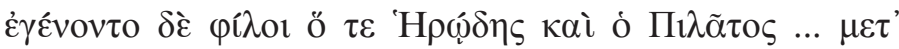

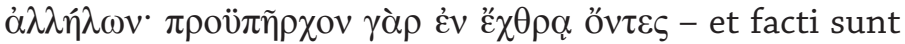
amici Herodes et Pilatus ... nam antea inimici erant - Lk 23,12

Jasno je da nema nikoga tko bi Stvoritelja kao vrhunsko biće mogao učiniti utočištem kao i to da su Herod i Pilat sklopili prijateljstvo sami, bez ičijega posredovanja. Tako se tumači i 'postati odrastao čovjek' u (7). Štoviše, čak i sam početni trenutak preobrazbe može postati nevažan ostavljajući glagolu ulogu puke spone. U to se možemo uvjeriti čitajući hrvatsku inačicu psalamskoga stiha jer smo jadni i nevoljni, koji u Pariškom zborniku glasi niĉi stvoreni esmo vel'mi (30). Subjektu je pred očima samo nevolja koja ljude u čije ime govori tišti ovdje i sada, a njezin uzrok i točno vrijeme nastanka padaju u drugi plan.

Uvid u pisane spomenike potvrđuje zakonitost dobro poznatu iz opisa drugih sintaktičkih pojava: tekstovi naslijeđeni iz starocrkvenoslavenskih prijevoda oslonjenih na grčki, malo ili nimalo prilagođeni latinskomu, sustavno se suprotstavljaju onima izvorno prevedenima s latinskoga jezika. Tipični su predstavnici posljednje skupine Kožičićev Misal hruacki (MKož) i

\footnotetext{
16 U suvremenom hrvatskom jeziku prijevod glagolom postati mnogo je običniji od prijevoda glagolom biti. Tako primjerice (7) glasi: Kad sam postao muž ili A kad postadoh zreo čovjek. Druga je mogućnost glagolski predikat, kao (11) se ... sprijateljiše prema postadoše prijatelji. O tome dalje u odjeljku 4.3.

17 Potvrda iz Misala hruackog pruža nam ujedno priliku da ju usporedimo s primjerom (7). Zahvaljujući različitim oblicima za 3. lice dvojine aorista bista i imperfekta běhota ovaj je tekst i bez pomoći priloga prěe lako protumačiti kao 'postali su prijatelji' ... 'prije su bili neprijatelji'. U primjeru (7), naprotiv, jednaki oblik bist' nije dovoljan za puno razumijevanje teksta. Za to je bio nuždan kontekst.
} 
Pariški zbornik (CPar). Kako bi se vidjelo koliki je upliv latinskoga jezika, usporedit ćemo Misal hruacki, u cijelosti ponovo preveden s latinskoga, s ostalim hrvatskoglagoljskim misalima, ${ }^{18}$ a psaltirski dio Pariškog zbornika s Lobkowiczovim psaltirom. Razdioba glagola biti i stvoriti u građi nije, razumije se, u potpunosti pretkažljiva pa se s jedne strane rješenju s glagolom stvoriti katkada priklanjaju i oni spomenici za koje to nije prvi izbor, kao Lobkowiczov psaltir (14), dok se s druge strane ni prevoditelji s latinskoga, kao Kožičić19 (15), ne drže slijepo svojega predloška.

\section{Oblik predikatnog imena}

Činjenica da je hrvatski crkvenoslavenski tekst noviji prijevod $s$ latinskoga može utjecati i na ustroj predikata, a ne samo na odabir glagola.

\subsection{Imenica i prijedložni izraz}

Glagolima biti i stvoriti zajedničko je predikatno ime u nominativu. Ono je i najčešće. ${ }^{20}$

(16) s'tvorena e(stb) juděě stina ego iz(drai)lı oblastb ego CPar

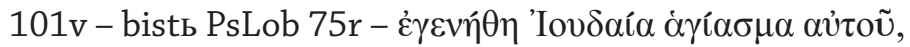

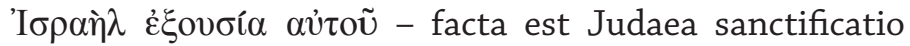
eius, Israel potestas eius - Ps 113,2

18 Ne ulazeći u pojedinosti dovoljno je upozoriti kako u njihov sastav ulaze dvije skupine tekstova. Prvi su naslijeđeni i podvrgnuti višestrukim redakcijama, a drugi su izvorni hrvatskocrkvenoslavenski, prevedeni s latinskoga. O biblijskim prijevodima usp. Badurina Stipčević (2016) i tamo navedenu literaturu.

19 „Kožičić ne preslikava slijepo latinske konstrukcije samo radi približavaja predlošku, već latinski jezik shvaća ponajprije kao poticaj i primjer gradnje vlastitita književnoga jezika te njegova oblikovanja na jasnim sintaktičkim načelima." (Eterović, Vela 2013: 118).

20 Odabrani primjeri s glagolom stvoriti u hrvatskoglagoljskim tekstovima: s(lovo) stvoreno b(i)si pl'tb $\mathrm{BrN}_{2}$ 470b; dvarb stvorena esmb s(i)nu b(o)žiju $\mathrm{BrN}_{2} 412 \mathrm{c}$ ianua facta sum; egda že stvorenь b(i)si mužь poětı ženu ot kolěne svoego imenemь an'nu BrVO 380d

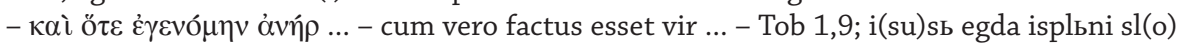
vo stvorenь bisi vladika iz(drai)lju BrVO 412c - factus est dux Israhel - 1Mak 2,55; ěže běše svobodnaě stvorena est' rabina BrVO 410c - quae erat libera facta est ancilla - 1Mak 2,11;

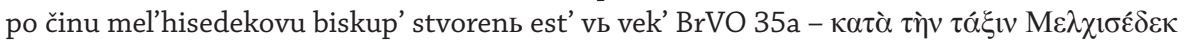

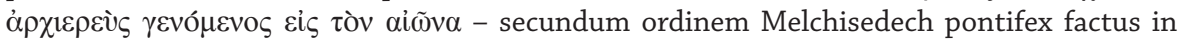
aeternum - Heb 6,20; vě h(rbst)běna esvě stvorena $\mathrm{BrN}_{2} 443 \mathrm{~d}$ - nos Christiani facti sumus. Pogledamo li pažljivije biblijske perikope, uvjerit ćemo se da prevladavaju one iz knjiga prevedenih s latinskoga. Usp. Badurina Stipčević (2016). 
(17) stvoren esi pomoĉnikb moi i priběžice moe CPar 52r -

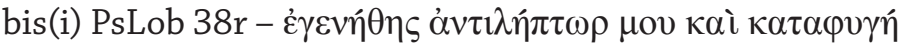
$\mu$ ov - quia factus es susceptor meus, et refugium meum Ps 58,17

(18) i slovo pltb stvorena b(i)si MKož 57d - b(i)si MHrv 10c -

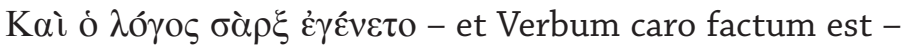
Iv 1,14

Uz oba glagola potvrđen je i prijedložni izraz vb + akuzativ.

(19) stvoren' bi g(ospod)ь mně v' priběžiĉe i b(og)b moi v' pomoć up'vaniě moego $\mathrm{CPar} 83 \mathrm{v}$ - b(i)si PsLob 63r -

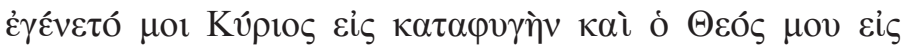

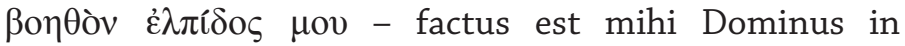
refugium, et Deus meus in adjutorium spei meae - Ps 93,22

(20) kamenь koga otvrgoše ziĵĉei sa stvorenь bi v' gl(a)vu

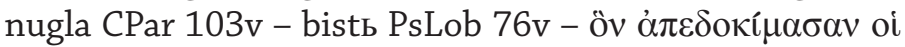

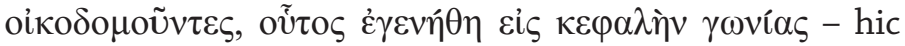
factus est in caput anguli - Ps 117,22

U sljedećem se psalmu (21) nominativ pomoĉnikb i prijedlog s akuzativom $v$ pribežiche smjenjuju, i to samo uz biti, a da za vb + akuzativ nema uzora u grčkome (niti u latinskome). Smjenjivanje je u vezi s razlikom $\mathrm{u}$ živosti referenta. U suvremenom hrvatskom jeziku apstraktni pojam rabi se u frazi $n a+$ akuzativ i u nominativu: Uvijek mu je bio na pomoć, Uvijek mu je bio pomoć, a imenica za osobu samo u nominativu: *Uvijek mu je bio na pomoćnika, Uvijek mu je bio pomoćnik. Tu na + akuzativ izriče namjenu. ${ }^{21} \mathrm{U}$ istoj je ulozi i novouvedeni prijedložni izraz vb + akuzativ u (21), ${ }^{22}$ za razliku od (5) u kojem akuzativ označuje pojam s kojom se subjekt poistovjećuje. Kada je u akuzativu imenica za neživo, moguća su oba tumačenja. Izjednačenje osobe kao subjekta s neživim mišljeno je tada metaforički.

\footnotetext{
21 Usp. Pranjković, Silić (2005: 226).

22 I u hrvatskoglagoljskim se tekstovima u tom značenju umjesto prijedloga $v b$ može upotrijebiti na s akuzativom: ne vidiši li êko krotostb b(o)žiê na pokaênie e(stb) - RegBen 3r (Mihaljević, Ana 2018: 65).
} 
(21) stvorenь e(stь) g(ospod)b priběžiĉe ubogu pomoĉnik' v potrěbah' CPar $13 \mathrm{v}$ - bist ... v pribežiĉe ... pomoĉnikb

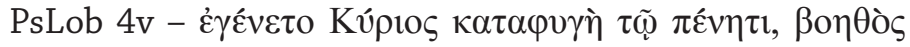

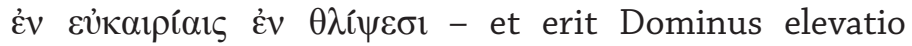
oppresso elevatio oportuna in angustia - Ps 9,10

Imenica u dativu potvrđena je samo u prijevodnoj inačici s grčkoga. U izrazima s glagolom stvoriti njemu odgovaraju ili nominativ (22) ili prijedlog $v b+$ akuzativ (23).

(22) stvoreni bismo ponošenie susědom' našim' CPar 71r -

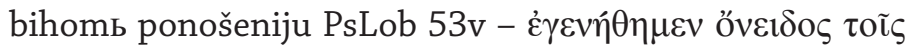
$\gamma \varepsilon i \tau$ coøv $\dot{\eta} \mu \tilde{\omega} v$ - facti sumus opprobium vicinis nostris Ps 78,4

(23) veĉe vsěh' nepriětel' moih' stvorenь essm' v' ponošenie susědom' moimb vel'mi i strah' znanim' moim' CPar

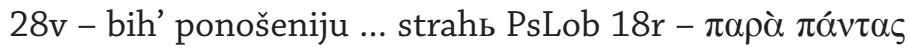

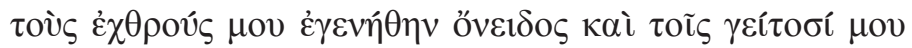

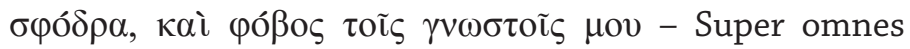
inimicos meos factus sum opprobrium, et vicinis meis valde, et timor notis meis - Ps 30,12

Instrumental je u našim tekstovima tek u začetku. ${ }^{23}$

\subsection{Izraz ěko / kako + imenica}

Postati sličan komu ili čemu, 'postati kao netko / nešto' (ěko / kako + imenica u nominativu) promjena je koja osobu ne zahvaća tako temeljito kao posvemašnja preobrazba, 'postati tko ili što' (imenica u nominativu).

(24) ap(usto)lь p(a)vlb progonit(e)lb h(rbst)benski vzv(ě) stitelb h(rbsto)vb stvorenb b(i)si $\mathrm{BrN}_{2} 401$ - Apostolus Paulus ex persecutorem Christianorum annuntiator factus est $^{24}$

23 Vidi primjer (6).

24 Silina promjene, u latinskom istaknuta prijedložnim izrazom ex persecutorem Christianorum, u prijevodu je oslabljena. 
U primjerima s ěko / kako riječ je o pripisivanju obilježja onoga s kime / s čime se uspoređuje onomu tko / što se uspoređuje. Govornik sebe uspoređuje s ćukom (25) i mijehom (26), a mjesec se uspoređuje s krvi (27). U primjeru (27) dovoljno je reći da je mjesec kao krv jer je pojmu 'krv' lako pripisati svojstvo 'crven'. Istu misao moguće je prenijeti i metaforički, brisanjem ěko / kako, čime se dva pojma izjednačuju. Ukoliko pak nije jasno o kojem je svojstvu riječ, nužno ga je izraziti s pomoću pridjeva. Tako iz pojma 'dlakava kostrijet' (27) nije pretkažljivo svojstvo 'crn', pa su u pomoć pozvani pridjevi $\mu \varepsilon \hat{\lambda} \lambda \alpha \varsigma$, niger i mračan. Rečenica slbnce bist' mračno ěko vrětiĉe vlasěno s pridjevom mračno pripada stoga sljedećem odjeljku. ${ }^{25}$

(25) s'tvoen' bih' kako noĉni vranı na visocě CPar $87 \mathrm{v}$ - bihь

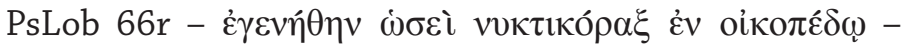
factus sum sicut nycticorax in domicilio - Ps 101,7

(26) stvorenь bih' kako mih' na mrazě CPar 107v - bihь PsLob

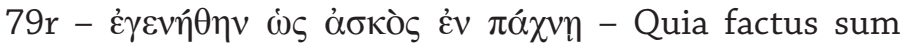
sicut uter in pruina - Ps 118,83

(27) (i trusb veli bist') i slbnce bist' mračno ěko vrětiĉe vlasěno i měsecb bist' ěko krbvb BrVO 270b - stvoreno bis(i) ...

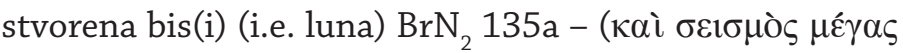

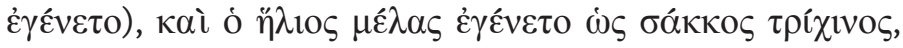

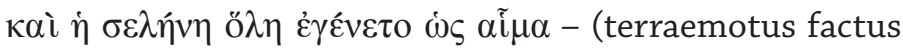
est magnus) et sol factus est niger tamquam saccus cilicinus et luna tota facta est sicut sanguis - Otk 6,12

\subsection{Pridjev}

Ograničimo li se na dva spomenika, Pariški zbornik i Lobkowiczov psaltir, pridjeva ne manjka, ali oni u njima nisu jednako zastupljeni. Uzrok su tomu različiti izvornici. Glagoljaški pisci, prevoditelji s latinskoga rabe izraz

\footnotetext{
25 Za riječ kao u primjerima Djevojka pjeva kao slavuj, Ona se kao mati brine za svoju djecu i ljut kao ris Pranjković veli da „[s]luži kao sredstvo kondenzacije iskaza, odnosno kao sredstvo preoblikovanja verbalnih konstrukcija u nominalne" (Pranjković 2013: 218). Tako se tumači prvi dio primjera (27) i slbnce bist' mračno ěko vrětiĉe vlasěno. Njegov drugi dio i měsecb bist' ěko krbvb pogađa kondenzacija drugoga stupnja kojom se jedan tip nominalnih konstrukcija, pridjevni preoblikuje u drugi, imenički. Kondenzacija prema tome teče u smjeru sve veće nominalnosti: $\mathrm{V}[+\mathrm{V},-\mathrm{N}] \rightarrow \operatorname{Adj}[+\mathrm{V},+\mathrm{N}] \rightarrow \mathrm{N}[-\mathrm{V},+\mathrm{N}]$.
} 
stvorenb estb + pridjev, oponašajući latinski dekomponirani predikat factus est + pridjev, a naslijeđeni se tekstovi ugledaju u grčki, u kojem prevladavaju glagolski predikati. ${ }^{26}$ Katkada ipak i prevoditelji s grčkoga posežu za pridjevom. Dokazuje to Lobkowiczov psaltir u (28).

(28) vsi ... neugod'ni stvoreni sut' $C P a r 16 r$ - něključimi biše

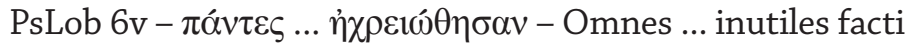
sunt - Ps 13,3

U sljedećim primjerima predstavljeni su nepodudarni predikati koji su posljedica prijevoda s latinskoga ili grčkoga - imenski s pridjevom ili glagolski. Osim različita ustroja oni su u hrvatskoglagoljskim usporednim tekstovima iz svojih predložaka naslijedili i pokoji pomak u značenju.

(29) čudanь stvorenь e(stb) razum' tvoi ot' mene CPar $118 \mathrm{v}-$

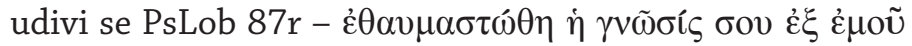
- Mirabilis facta est scientia tua ex me - Ps 138,6

(30) niĉi stvoreni esmo vel'mi CPar 71r - obniĉahomb - PsLob $53 \mathrm{v}-\dot{\varepsilon} \pi \tau \omega \chi \varepsilon v \dot{\sigma} \alpha \mu \varepsilon v \sigma \varphi o ́ \delta \rho \alpha$ - pauperes facti sumus nimis - Ps 78,8

(31) velmi gluboka stvorena sutb pomišleniě tvoě $C P a r ~ 81 v-$ uglubiše se PsLob $62 r$ - $\sigma \varphi o ́ \delta \rho \alpha$ غ̇ $\beta \alpha \theta u ́ v \theta \eta \sigma \alpha v$ oi $\delta 1 \alpha \lambda o \gamma 1 \sigma \mu o i ́$ бov - profundae facta sunt cogitationes tuae - Ps 91,5

(32) mr'ski stvoreni sut' CPar 16r - omraziše se PsLob 6v -

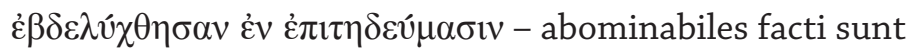
- Ps 13,1

(33) podoban' stvoren' est' im CPar 45r - upodobi se PsLob

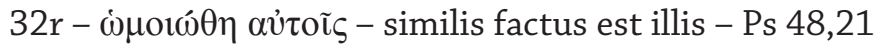

26 Još primjera s pridjevom uz izraz stvorenb biti u različitim vremenima i licima iz različitih tekstova: i podobanь stvorenь bisi lıvu v dělěhь svoihь VrVO 414b - Similis factus est leoni in operibus eius - 1Mak 3,4; stvorenь esьm' mni samomu težakb CPar 197r - factus sum mihimet ipsi gravis - Job 7,20; što $t(a) k o$ bezumna stvorena esta $\mathrm{BrN}_{2} 453 \mathrm{c}$; ěko krh'ci

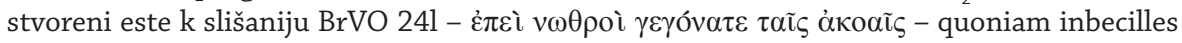
facti estis ad audiendum - Heb 5,11; beli stvoreni sutb nazarěi ego $\mathrm{BrN}_{2} 355$ c candidi facti

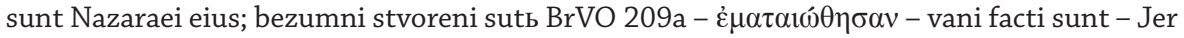
2,5 
(34) mně inoplemen'nici priět(e)li stvoreni biše $\mathrm{CPar} 97 \mathrm{r}$ -

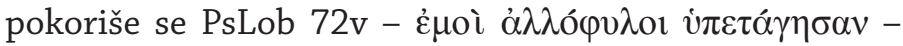
mihi alienigenae amici facti sunt - Ps 107, 10

(35) tužanb stvorens bih' CPar 36r - postradahs PsLob 24r غ̇ं $\alpha \lambda \alpha \iota \pi \omega ́ \rho \eta \sigma \alpha$ Ps 37,7 - miser factus sum - Ps 37,5

Neki primjeri nude zanimljiv spoj sintetičkog i analitičkog izričaja unutar iste rečenice.

(36) (i.e. grěsi) lěki sněgb obělějut' ... lěki vlna běla běli budutb $\mathrm{BrVat}_{5} 4 \mathrm{a}-$ obělějut' $\ldots$ obělějutb MVat $457 \mathrm{a}-\lambda \varepsilon v \kappa a v \tilde{o}$.. $\lambda \varepsilon v \kappa \alpha v \tilde{\omega}$ - dealbabuntur ... velut lana erunt - Iz 1,18

(37) upodobi se skotom' nesmisl'nim' i podoban' stvoren' est' im CPar 45r - priloži se ... upodobi se PsLob 32r $\pi \alpha \rho \alpha \sigma v v \varepsilon \beta \lambda \eta \dot{\theta} \theta$... $\dot{\omega} \mu \mathrm{o} \omega \hat{\theta} \theta \eta$ - comparatus est ... similis factus est - Ps 48,21

Prvo o primjeru (36). Vatikanski misal Illirico 4 ima u ulozi predikata oba puta punoznačni glagol obělějutb kao grčki, a Vatikanski brevijar Illirico 5 glagolskom predikatu obělějut' suprotstavlja pridjev iz kojeg je taj glagol tvoren i glagol biti, dakle běli budutb, kako je i u latinskom. U primjeru (37) Lobkowiczov psaltir slijedi grčki time što su mu oba predikata glagolska, priloži se, upodobi se, dok je u latinskom i Pariškom zborniku takav samo prvi, upodobi se. Drugi je imenski i sastoji se od glagola stvoriti i pridjeva koji dijeli isti korijen s prethodnim glagolom, podoban' stvoren' est'. Za razliku od ostalih primjera, onaj pod brojem (36) odnosi se na budućnost.

\subsection{Ostali oblici}

Nominativ, dativ i instrumental imenice te prijedložni izraz $v b+$ akuzativ u imenskom predikatu izražavaju subjektov identitet, kazuju što on jest ili postaje (pa i u prenesenom smislu: spas, utočište i sl.). Uloga je pridjeva, naprotiv, da ga opiše pridajući mu kakvo svojstvo. Istoj svrsi služe najrazličitiji padežni i prijedložni izrazi s prvotnom ulogom atributa ili priložne oznake, ugrađeni u imenski predikat. ${ }^{27}$ Njihova raščlamba, kao i

27 Vidi Večerka (1993: 120-121). Primjer je za to (21) v priběžicie. 
participa (2), infinitiva i zavisne rečenice (1), koji u predikatno ime uvode glagolski element, prelazi okvire ovoga rada. ${ }^{28}$

\section{Glagoli nepotpuna značenja}

U ovom odjeljku predstavljeni su glagoli koji leksički obogaćuju sponu biti, a to su neprelazni glagoli prěbiti, ostati i dr. te prijelazni glagoli u pasivu. Tek prošireni pripadajućim imenskim dijelovima predikata oni prenose punu obavijest. Prema značenju razvrstani su u šest skupina.

\subsection{Značenje 'ostati'}

Za prenošenje toga značenja zaduženi su glagol ostati i dva glagola tvorbeno povezana s glagolom biti: prěbiti, prěbivati. Uz glagole prěbiti 'ostati' u aoristu, perfektu i prezentu u službi futura te prěbivati 'ostajati' u prezentu potvrđeni su kao imenski dio predikata pridjev i imenica, pri čemu samo potonja omogućuje odabir instrumentala.

(38) tako i d(ě)va $\mathrm{m}(\mathrm{a})$ riě rodi $\mathrm{g}($ ospod)a na nevrěždena prebi $\mathrm{BrLab}_{2} \mathrm{I} 25 \mathrm{~b}$

(39) po porodě d(ě)voju nevrěždena prěbila esi - $\mathrm{BrVb}_{4} 33 \mathrm{~d}$ post partum virgo inviolata permansisti

(40) i v(a) v(ě)kb prebudeši d(ě)voju $\mathrm{BrN}_{2} 468 \mathrm{~d}$ - et in aeternum permanens virgo

(41) ěkože i b(la)ž(e)naě d(ě)va m(a)riě počbnši děvoju prěbivaetb $\mathrm{MVat}_{4} 98 \mathrm{a}$

Istome značenjskom krugu pripada i glagol ostati, kojemu je korijen potvrđen i u glagolu vstati.

(42) si tvr'di i ne gonuĉi se ostali bi BrVO 73b - ipsi solidi atque immobiles remanserunt

28 Tek kao ilustraciju vrijedno je zabilježiti, primjerice, kvalitativni genitiv v'zrasta visoka suprotstavljen predikatnom pridjevu velici. Tu je predikatni nominativ velici upotpunjem kvalitativnim instrumentalom stanom'. Primjeri glase: iže ot začela biše v'zrasta visoka MNov

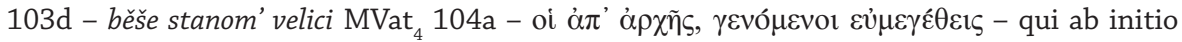
fuerunt statura magna - Bar 3,26. 


\subsection{Značenje 'biti stvoren, biti učinjen'}

To je značenje oprimjereno prijelaznim glagolom stvoriti (13) te glagolom postaviti, koji u svojoj osnovi nosi isti korijen kao i neprelazni glagoli ostati (42) i vstati (44):

(43) simunь zelotb ... po mucě ěkov'li voleju vs(ě)hь ap(usto)lь er(u)s(oli)mskoi cr(ě)kvi b(i)sk(u)pь bě postavlenь $\mathrm{BrN}_{2}$ 496b - Simon Zelotes ... Hierosolymitanae ecclesiae episcopus est ordinatus

\subsection{Značenje 'postati'}

Značenje 'postati' prenosi glagol vstati, u psalmu popraćen akuzativnim prijeložnim izrazom $v b+$ akuzativ (44), već viđenim uz glagole biti i stvoriti.

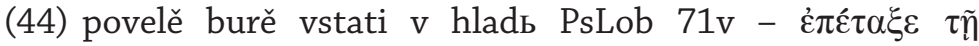

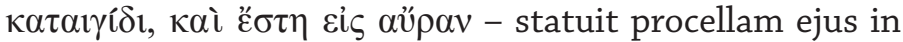
auram - Ps 106,2929

Već se za glagol biti pokazalo da on ne mora nužno biti tek spona jer je prigodice opremljen i značenjem 'postati', a njegov vidski parnjak bivati značenjem 'postajati'. Vidjeli smo brojne prijevodne inačice glagola biti s pomoću n-pasiva glagola činjenja stvoriti. Ukidanje činitelja ima za posljedicu pretakanje značenja 'biti stvoren' u pojednostavljeno '(iz sebe) postati'. To se značenje iščitava i iz se-pasiva glagola učiniti (45).

(45) vidiv'ši zmiě toga učini se plt' nee $\mathrm{k}(\mathrm{a}) \mathrm{ko}$ trava zelena COxf 26a - facta est ut herba pallida

Značenje 'postati' katkada se izražava i slobodnije, premda u izvorniku nema ničega što bi priječilo prijevod glagolima biti i stvoriti, kako je uobičajeno.

(46) iže běhu suhaě vb ezera obratet se i žeždućei vb istočniki

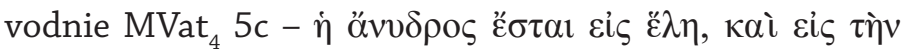

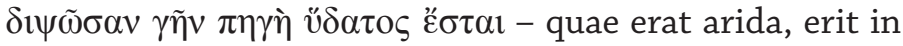
stagnum et sitiens in fontes aquarum - Iz 35,7

29 Taj psalam iz Sinajskog psaltira navodi Večerka kao potvrdu spone u značenje 'biti, postati' (Večerka 1993: 119). 
(47) kada kon'ča m(o)l(i)tvu tadae božiim' hoteniem' vsta se

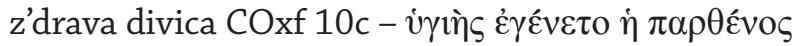

Primjer (46) podsjeća na neke ranije, u kojima je trajanje prekinuto novim događajem. U (7) i (15) prekretnica se zbila u prošlosti, a u ovom se kao u (5) očekuje u budućnosti. Glagol obratiti se umjesto statičnoga glagola Eĩvor / esse naglašava silinu same preobrazbe. Kao i kod glagola stvoriti se tu je se čestica, a ne akuzativ povratne zamjenice. Izraz vsta se z'drava (47) radije ćemo prevesti kao 'posta zdrava, ozdravi' nego 'usta zdrava', iako je

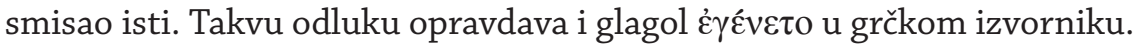

\subsection{Značenje 'praviti se, pretvarati se'}

U prethodnim su odjeljcima prikazana zbivanja u kojima subjekt nije djelatan. Sudionici sljedećih događaja opisanih glagolima činjenja činiti, učiniti, dělati, tvoriti i stvoriti osobno su zauzeti da se ostvare kao pojam izrečen imenicom ili pridjevom. U konačnici oni jesu - ili se prave da jesu drukčiji nego prije, ili su pak postali - ili se prave da su postali - netko drugi / nešto drugo. Nije uvijek jasno je li preobrazba stvarna ili hinjena i tu nastaje problem sintaktičke interpretacije, naime je li riječ o glagolu tvoriti 'činiti, praviti' i povratnoj zamjenici se ili već o glagolu tvoriti se 'praviti se, graditi se', ${ }^{30}$ gdje je se čestica. ${ }^{31}$ Odluka je utoliko teža što je razlika među dvama tumačenjima katkada gotovo neuhvatljiva.

(48) ti č(lově)kb buduĉb tvoriši se samı b(og)b MHrv 63b - ti č(lově)kb sucii samb sebě b(og)a tvoriši - MKož $58 c$ - ov̀

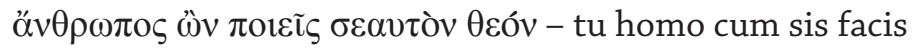
te ipsum Deum - Iv 10,33

(49) o gorko i čemerno tim' ženam' ke lica svoě pomazaju i lipše se čine nere ih' e bog' učinil' CAc 75v

(50) vi se gbotri dělate a ne drъžite kako dostoino estь CPar $286 r$ - vos facitis patres

(51) greduĉi toi ženi na misu utaknu ju děv(a)l' hodcem' se učinivši CGrš $178 \mathrm{v}$

30 S istom se nedoumicom susreću autori pri raščlambi rečenica s infinitivom. Usp. Vela (2018: 156).

31 Usp. Silić, Pranjković (2005: 40-41). 
(52) i pooĉutiv' e vragb i s'tvori se ribu Amul

Ako je se u (48) - (50) povratna zamjenica u akuzativu, tada su i sinkretski nominativno-akuzativni oblici proširka sintaktički akuzativi. Za nove, iz genitiva posuđene oblike objekta sebe (u pismu sebě) i proširka boga u drugoj potvrdi (48) jasno je na prvi pogled da su akuzativi, a zamjenica samb dio je subjektne skupine u nominativu. Taj primjer prema tome izlazi iz okvira naše teme. Prva je inačica toga primjera se samb $b(\mathrm{og}) b$ također potvrda akuzativa, što pretpostavljamo na temelju usporednica iz klasičnih jezika u prilogu.

$\mathrm{Na}$ dva mjesta rabi se instrumental (51) i (52), ${ }^{32}$ svojstven i suvremenom hrvatskom jeziku. Rečenicu toga jezika Nemoj se praviti žrtvom možemo parafrazirati na dva načina: a) Nemoj sebe praviti žrtvom ${ }^{33}$ (usp. Nemoj ga praviti žrtvom) i b) Nemoj se praviti žrtva. U prvom slučaju povratna zamjenica se / sebe izravni je objekt u akuzativu uz prijelazni glagol praviti, a u drugom je neprelazni glagol praviti $s e^{34}$ proširen nominativom ili instrumentalom. Primjeri (49) - (52) svi su redom iz jako pohrvaćenih tekstova. Oblik se kao čestica (a ne kao povratna zamjenica) i nominativnoakuzativni oblici lipše (49) i gbotri (50) shvaćeni kao nominativi priskrbili bi rečenicama značenje 'pretvarati se da si netko / nešto / nekakav', umjesto 'pretvarati sebe u nekoga / nešto / nekakvo'. Dvojako tumačenje nudi i instrumental u (51), ali ne i (52). Tu nam pomaže znanje o svijetu. Osoba (ovdje vrag) ne može se uspješno pretvarati da je riba ako se u nju doista ne pretvori. Pitanje može li se i za hrvatskoglagoljske tekstove pretpostaviti dvojako 'pretvarati se' ostaje, u nedostatku primjera s nesumnjivim morfološkim nominativom predikatnoga imena, i dalje otvoreno.

\subsection{Značenje 'činiti se, izgledati'}

Niz primjera izriče da se pojam iskazan subjektom osjeća, čini, prepoznaje, pokazuje ili izgleda kao tko, što ili kakvo. U prenošenju toga

32 Novouspostavljeni instrumental i morfološki odudara od kanonskoga oblika. Autorica koja je opisala hrvatskoglagoljski amulet tipa Sisin i Mihael navodi više takvih instrumentala: vsu tainu božiju, ednu ruku, sn'cem i lunu, s'tvori se ribu, svetu vodu (Pantelić 1973: 179).

33 Još je jasnije: Nemoj od sebe praviti žrtvu gdje se glagol praviti razlikuje sintaktički.

34 Tako se glagol praviti se i njemu slični navode u gramatikama suvremenoga hrvatskoga jezika; usp. Katičić (1986: 39-40); Silić, Pranjković (2005: 291). 
značenja sudjeluju glagoli vidnog opažanja, mišljenja, vjerovanja i znanja i oni koji o čemu izvješćuju ili kojima se što ustanovljuje.

(53) nepodobn' nam' vidit se život' ego $\mathrm{MVat}_{4} 68 \mathrm{~b}$ - ỏvó $\mu$ oı

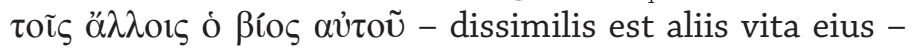
Sap 2,15

(54) vidiš' bo se nam' kako slobodan' COxf 18a - appares enim nobis liber

(55) stvori eže tebě do(bro) vidit' se BrVO 312c - Пoícı tò

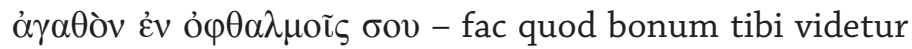
$-1 \mathrm{Kr} 1,23$

(56) ěko oni v toižde věrě zli sut' veĉe slama neže plěveli mnet' se BrVO $122 d$ - illi qui in eadem fide mali sunt, palea potius quam zizania reputantur

(57) v(a)sь bo mir' kap'la vodonos'naě v'měnaet' se i vsi věci

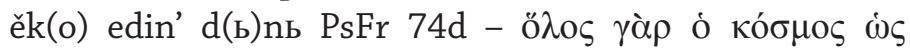

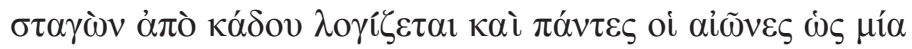
$\dot{\varepsilon} \mu \varepsilon ́ p \alpha-$ CommPs 89,5

(58) sь iže g(lago)let' e edinočedi s(i)nь b(o)ži věruet se $\mathrm{BrVO}$ $305 c$

(59) petb ubo talanatı danie petihь umovb eže e(stb) vnešnihь svěsti razuměet' se $\mathrm{BrN}_{2} 341 \mathrm{~b}$ - skažuet se $\mathrm{BrAc} 55 \mathrm{a}-$ quinque ergo talentis donum quinque sensum, id est, exteriorum scientia exprimitur

(60) velika bogoljubiě i věri ukazuet' se siě žena $C P a r 170 v-$ magna devotionis et fidei haec mulier ostenditur

(61) ot pomoĉi i zaĉuĉeniě ili prebivaniě preb(la)ž(e)ne b(ogo) r(odi)ce ěvil' se bi bez'daranь CPar 168v - immunis appareret

(62) aĉe každo zavistiju ili gorěstiju poraženь gněva ěrosti naplnenь poznaet se $\mathrm{BrN}_{2} 352 \mathrm{~d}$ - unusquisque invidiae velodii veneno percussus iracundiae furore repletus 
(63) b(la)ž(e)nь m(u)žb ki obrětenь e(stb) bes' poroka ... i svršenb obrěte se MHrv 193d-194a - obrěte se ... naidě

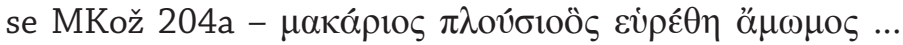

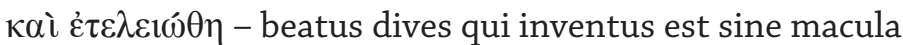
... et perfectus est - Sir 31,8...10

(64) bes' prikosneniě studa obretena esi mati $s p(a) s(i) t(e) l a$ $\mathrm{BrN}_{2} 375 \mathrm{c}$

(65) obrazomb obrěte se k(a)ko č(lově)kb MHrv 69b - obrěĉenь

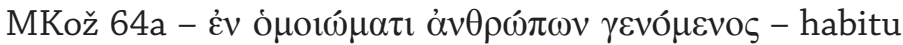
inventus ut homo - Fil 2,7

Iako u predočenoj građi za to nema primjera, iskustvo suvremenoga hrvatskoga jezika uči nas da se i glagoli činjenja mogu uporabiti u promatranom značenju: Meni se učinila poznata ili Sada već djeluje spreman na sve. Kako bi se izbjegla svaka nedoumica, pojedini glagoli djelovanja specijalizirali su se ili za izricanje značenja 'izgledati pričinjati se': Ona se čini bolesna ili 'praviti se, pretvarati se': Ona se pravi bolesna.

\subsection{Značenje 'zvati se'}

Izdvojeno će se promotriti velika skupina glagola sa zajedničkim značenjem 'zvati se'. Među njima po zastupljenosti i množini oblika prednjače glagoli s korijenom *rek. Promjenom prijevojnoga stupnja (nareĉi - naricati) tim se glagolima mijenja glagolski vid, a dometanjem prefiksa (nareĉi prinareĉi) značenje. Potvrđeni su u se-pasivu, $n$-pasivu, pa čak i u $m$-pasivu.

(66) plbtskihь radi i besplıtnihb $s(i) n b$ višnago narečet' se

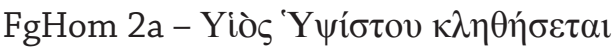

(67) k tomu ne narečet' se ime tvoe avram' nь budetb ime tvoe

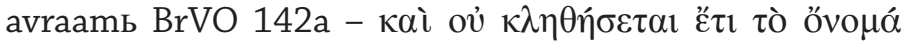

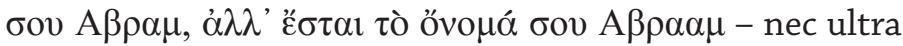
vocabitur nomen tuum Abram sed appellaberis Abraham - Post 17,5

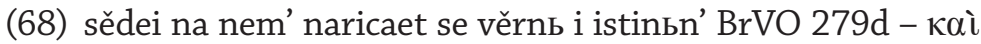

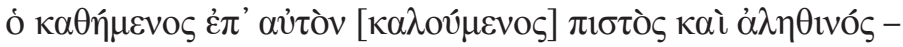
et qui sedebat super eum vocabatur Fidelis et Verax vocatur - Otk 19,11 
(69) věrova avraam' b(og)u i vměni se emu v pravdu i sego radi drug' b(og)u narečen' est' BrVO 148a

(70) ime rěcě edinoi pisionь ... rěka že treta tigbr' ... rěka že

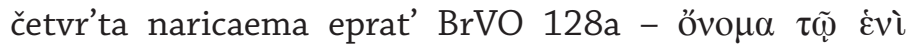

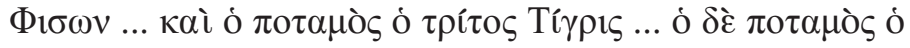

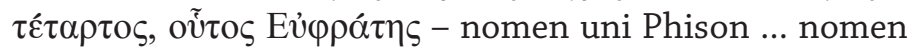
vero fluminis tertii Tigris ... fluvius autem quartus ipse est Eufrates - Post 2,11...14

(71) osipa naricaemago virsavu iže prinarečen' bisi just' $\mathrm{MVat}_{4}$ $181 a$ - ki pričten' bis(i) just' Hrv 156c - iže narečěnь

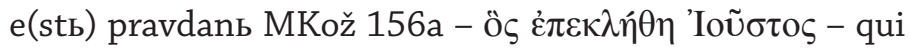
cognominatus est Iustus - Dj 1,23

Primjer (67) zorno oslikava bliskost glagola imenovanja s glagolom biti, kako u grčkom tako i u slavenskom prijevodu. Uzajamnu zamjenjivost izraza biti i zvati se zapažamo i u okolinama bez zalihosti osigurane imenicom ime u kojoj je već sadržan pojam nazivanja: To se zove sreća. - To je sreća. Pridjevi se pri nadijevanju imena poimeničuju (68) ${ }^{35}$. U latinskome je to odmah razvidno iz pravopisa. Rijetka je pojava particip prezenta pasiva, kao u (70). Značenje imenovanja preneseno je tu na tri načina, a u svima je prema grčkom izostao glagol biti. ${ }^{36}$

Glagolski niz zvati, vzvati, vzivati ugrađen je u predikate s česticom se i $s n$-pariticipom.

(72) izide měsecь sedmi iže zovet se adarb BrVO 404a - ö $\varepsilon \dot{\sigma} \sigma \iota v$ A $\delta \alpha \rho$ - qui vocatur Adar - Est 3,7

(73) i kamenь sa iže vbzvěsь v znamenie i vzovet' se dom' b(o)ži $\mathrm{BrVO} 167 \mathrm{~b}$ - et lapis iste quem erexi in titulum vocabitur Domus Dei - Post 28,22

(74) vsa cr(ě)ki ...ediněmb imenem’ d(ě)va e(stb) vbzvana $\mathrm{BrN}_{2}$ $349 d$ - tota Ecclesia uno nomine virgo est appellata

(75) iže paraklit' vzivaeši se BrVO 303d - qui diceris Paraclitus

35 Usp. Vince (2017: 193-195).

36 U prvoj i drugoj potvrdi riječ je o sponi, a u trećoj o pomoćnom glagolu. 
Smjena glagola glagolati i govoriti pokazatelj je veće ili manje konzervativnosti teksta.

(76) iže ... prevznašaet se nadb vs(a)koe eže govorit se $b(\mathrm{og})_{\mathrm{b}}$

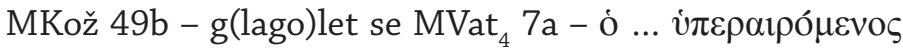

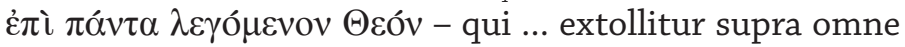
quod dicitur Deus - 2Sol 2,4

(77) vzidi v(b) er(u)s(o)lim' ... k vratom' ka zlata govoret' se ěko pozlacena sut' $\mathrm{BrLab}_{1} 179 \mathrm{~b}$

(78) pl'na m(i)l(o)sti d(ě)va $\mathrm{m}(\mathrm{a})$ riě vzvěĉaet se $\mathrm{BrN}_{2} 474 \mathrm{a}-$ plena gratia virgo Maria pronontiatur

Prefigirani glagol proglagolati popraćen je glagolom vzvati u istoj rečenici.

(79) žena bl(u)dna prog(lago)lana est' sět' d'ěvla i d(u)šelovica ... i ot samago muža adama vzvana est' mužehotica CVinod 62b

Ulogu veznoga sredstva preuzimaju nadalje glagoli nepotpuna značenja děti, skazovati, praviti, vzvěceati i ěvlati. S glagolom děti nadmeću se glagoli govoriti i naricati u drukčijim morfosintaktičkim sklopovima, ali u istom značenju (80). Prvi je bezlična rečenica ${ }^{37}$, a u drugom je odnosna rečenica sažeta u particip prezenta pasiva koji se postavši atributom stao sklanjati kao u grčkom.

(80) iměše bo tada ednoga uznika naročita ki diše se barabasb CPar 243v - komu se baraba govoraše MKož 66c -

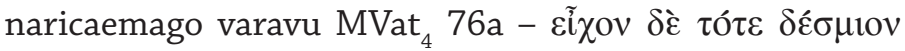

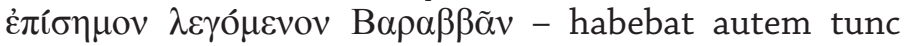
vinctum insignem qui dicebatur Barabbas - Mt 27,16

(81) avep'salom' že o(tb)cb miru skazuet' se PsFr 2c -

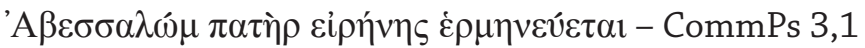

(82) varahiě v' ězicě $\mathrm{n}(\mathrm{a})$ šem$^{\prime} \mathrm{bl}($ (agoslovle)n' g(ospodb)nb pravit se $\mathrm{BrVb}_{1} 36 \mathrm{~b}$ - Barachia ... Benedictus Domini dicitur

37 Moglo bi se pomisliti da je Kožičić qui pročitao kao cui pa odatle dativ u prijevodu i promijenjen, ali jednako prihvatljiv sintaktički sklop. 
(83) aĉe dob'rorodna vzvěçaeši se i plemenita esi BrVat $_{6} 276 \mathrm{a}$ - ěvlaeši se BrPm 212b - v'zivaeši se $B^{2 L a b}{ }_{1} 31 d$ - si ingenua probaris

Na mjestu glagola glagolati dolazi i glagol imenovati (84) tvoren od korijena imenice ime, *imen-, dok imenica kao polazište za glagol znamenovati (85) nije potvrđena.

(84) pridosta po puti iže g(lago)let se apiě Vat ${ }_{19} 315 \mathrm{a}$ - imenuet se $\mathrm{BrN}_{2} 443 \mathrm{~b}$ - per viam qua Appia nuncupatur

(85) dělateli že vistinu godini prbvie i tretoe toli šestoe i devetoe prbvi oni evrěisci ljudi znamenujut se BrVO 129c - orator ergo mane, hora tertia, sexta, et nona, antiquus ille et Hebraicus populus designatur

Iz govornoga medija imenovanje prelazi i u pisani: ${ }^{38}$

(86) simun' kananěi ... se bo e(stb) iže v drugom' e(van)j(el)ii pišet' se zělot' BrPm 273d - Simon Cananeus ... ipse est qui in alio evangelista scribitur Zelotes

\section{Oblik predikatnoga imena uz nesamostalne glagole}

Kao i uz glagole biti i stvoriti, najčešći je oblik predikatnoga imena nominativ, bilo imenice bilo pridjeva. Iznimno se u instrumentalu uz glagole prěbiti i prěbivati pojavljuje imenica děva (40), (41). ${ }^{39}$ Pridjev nevrěždenb ${ }^{40} \mathrm{u}$ istoj okolini redovito je u nominativu (38), (39). Među imenicama u nominativu ima antroponima: avram' (67), just', (75), paraklit' (74), barabasb (80), zělot' (86) i toponima: eprat' (70), adar (72), apiě (84), redovito uz glagole imenovanja. Neki su od njih poimeničeni pridjevi: ${ }^{41}$ věrnb, istinbn' (68),

38 U slovenskom jeziku glagol pisati služi označivanju prezimena, koje je „službenije” od osobnoga imena. Tako pitanje o (osobnom) imenu glasi Kako se kličeš?, a o prezimenu Kako se pišeš? Ulogu imenovanja osobe povrh osobnoga imena dobio je u našoj građi glagol nareĉi obogaćen prefiksom pri- (71).

39 Ukoliko je u (51) značenje glagola učiniti se 'graditi se', ovamo spada i instrumentali hodcem'.

40 Sandra Požar uvjerljivo obrazlaže zašto taj oblik zanijekanog pasivnog preteritnog participa možemo već smatrati pridjevom. Vidi Požar (2017: 74-75).

41 U hrvatskoglagoljskim tekstovima ima mnogo vlastitih imena koja su po postanju pridjevi. Vidi Vince (2017). 
bl(agoslovle) $n^{42} g($ ospodb)nb (82). Ostale imenice potvrđene su ili samostalno: biskupb (47), do(bro) (55), d(ě)va (74), b(og)b (76), d(u)̌selovica, mužehotica (79) ili s različito ustrojenim atributima: kap'la vodonos'naě (57), edinočedi s(i)nb $b(o) z ̌ i ~(58)$, drug' b(og)u (69), dom'b(o)ži (73), sět' děvla (79), o(tb)cb miru (81), danie petihb umovb (59). I takvi sklopovi mogu postati vlastita imena: sinb višnago (66). Pridjevi katkada stoje sami: tvr'di (42), zelena (44), nepodobn' (53), bez'darans (61), zlata (77), dob'rorodna (83), a ima i onih s dopunom: pl'na $m(i) l(o) s t i(78)$, velika bogoljubiě i věri (60). Pasivni preteritni participi nevrždena (38), (39), gněva ěrosti naplnenb (62) i svršens (63) popridjevljeni su, a aktivni prezentski s česticom se kojim se prevodi latinski pridjev dolazi u paru s pridjevom tur'di $i$ ne gonuci ise (42). Prijedložni izraz v hladb (43) označuje identitet, a bes' poroka (63) i bes' prikosneniě studa (64) svojstvo. Prvi je tipično obilježje imenica, a drugi pridjeva. Na sličnost subjekta s kakvim pojmom izrečenim imenicom ili pridjevom upućuju ěko i kako:43 kako slobodan' (54), $k(a) k o$ č(lově) kb (65), éko edin' d(b)nb (57), a o višem stupnju njegove pokrivenosti prvim pojmom nego drugim svjedoči prilog veĉe: veĉe slama neže plěveli (56).

\section{Nefinitni oblici glagola biti i zavisna rečenica}

Za suvemeni hrvatski jezik utvrđen je malen broj glagola koji sudjeluju u dvojakim strukturama, od kojih je prva predmet ovoga rada, a druga je njezina parafraza uz pomoć izrične rečenice: Ona se čini luda / ludom - Čini se da je ona luda (Brač 2017: 31). Hrvatski glagoljaši raspolažu još dvjema mogućnostima izricanja istoga sadržaja a obje su prijevod latinske konstrukcije nominativa s infinitivom. ${ }^{44}$

$\mathrm{U}$ njima prema latinskom infinitivu glagola esse stoje participi $s i^{45} \mathrm{i}$ bivb i infinitiv biti.

\footnotetext{
42 Ovaj oblik prešao je put od participa preko pridjeva do imenice.

43 Ni latinski nam ne pomaže da sa sigurnošću utvrdimo je li u (44) put postala 'zelena kao trava' ili 'kao zelena trava'.

44 U novije doba nominativ s infinitivom opisan je u dvjema doktorskim disertacijama. U njima se može naći i literatura na koju se istraživanja autora nadovezuju. Prva je iscrpna raščlamba infinitiva i supina u svoj njihovoj sintaktičkoj raznolikosti (Vela 2018). Druga već u naslovu izrijekom spominje latinski jezik kao predložak hrvatskoglagoljskih prijevodnih tekstova (Mihaljević, Ana 2018).

45 Naveden je kanonski oblik si, iako se za nominativ jednine muškoga roda češće posuđuje akuzativni oblik suĉb, što je uobičajeno i za ostale glagole, a potvrđene su i druge inačice (RCJHR 2000: 157; HCSJ 2014: 185, 227).
} 
Participi glagola biti kao prijevodne inačice te konstrukcije slijede padež predikatnoga pridjeva, sročnoga sa subjektom koji je u nominativu. Prema latinskom infinitivu prezenta esse stoji particip prezenta, u našem primjeru ženskoga roda u nominativu množine suĉe, koji se slaže $\mathrm{s}$ pridjevom prave (86). Infinitiv perfekta fuisse prevodi se participom preterita. U primjeru (88) njegov je nominativ bivb u nominativu jednine muškoga roda, kao i pridjevi němb i slěpb. Osim svoje imenske naravi particip u toj ulozi iskazuje i onu drugu, glagolsku. Njegovim uklanjanjem rečenice bi doduše ostale ovjerene, ali bi se izgubio dio obavijesti, tj. podatak o vremenu zbivanja.

(87) četirihь ubo životnihь nogi prave suĉe naz(na)m(e)nujut se $\mathrm{BrN}_{2} 329 \mathrm{~d}$ - zn(a)m(e)nujut se BrBar 470b - quattuor ergo animalium pedes recti esse describuntur

(88) běsni že sa vb ev(an)j(e)li b(la)ž(e)n(a)go matěě ev(a)nj(e) lista ne tıkmo němb na i slěpь bivb pravitb se FgLab $2 \mathrm{~d}$ Daemoniacus iste ... non solum mutus, sed et caecus fuisse narratur

Drukčije je s infinitivom biti prema latinskome esse (89), (90) i fore (91). Njegov jedinstveni oblik onemogućuje razlikovanje sadašnjosti i budućnosti i time osiromašuje značenje izvornika.

(89) malo že sutb vsa dobraě života sego ... aĉe i velika mnet' se biti viducimb - $\mathrm{BrN}_{2}$ 341d pauca quippe bona sunt omnia praesenti vitae quamlibet multa esse videantur

(90) vistinu s(ve)taě cr(ě)ki c(ě)sarstviě $\mathrm{n}(\mathrm{e}) \mathrm{b}(\mathrm{e}) \mathrm{sk}(\mathrm{a})$ go imenemb desetimb d(ě) $v(\mathrm{a}) \mathrm{mb}$ podobna biti v'zvěçaet' se $-\mathrm{BrN}_{2}$ $348 \mathrm{~b}$ - sancta Ecclesia decem virginibus similis esse denuntiatur

(91) vlaĉi začetiě ee $d(b) n b$ vekši biti ukazuet' se nere roeniě CPar 151v - conceptionis eius dies maior fore approbatur

Neočekivan je nominativ s infinitivom u primjeru (92), jer bismo prema latinskome očekivali samo predikatno ime. 
(92) c(ěsa)rstvo $\mathrm{n}(\mathrm{e}) \mathrm{b}(\mathrm{e})$ sko vistinu č(lově)ku domovitu podobno biti pravit se - regnum caelorum homini patri familias simile dicitur ${ }^{46}$

Rijedak je slučaj da se glagol ne upotpunjuje niti imenom (imenicom ili pridjevom) niti nefinitnim oblicima glagola biti, nego zavisnom rečenicom $\mathrm{s}$ istim tim glagolom. ${ }^{47} \mathrm{U}$ nedostatku sigurnoga primjera ponuđen je ovaj u kojem će se prije biti objekt negoli sastavni dio glagola kazati se, sudeći bar prema grčkome i latinskome.

(93) kazati se da on' bil' bi b(og)ь BrLab 2 229 c - kažujuĉ se

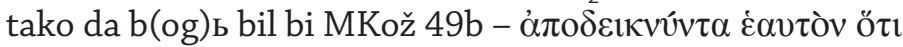

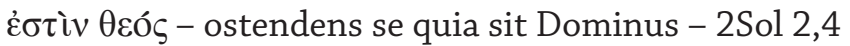

Poučna je usporedba s nekim suvremenijim prijevodima istoga retka na srpski i hrvatski jezik. Karadžićev glasi pokazujući sebe da je Bog, a Rupčićev pokazujući sebe kao da je „Bog”. Prvi u potpunosti odgovara grčkom, a drugi je hipotetičnost koja je u latinskome izražena konjunktivom, a u II. ljubljanskom brevijaru i Misalu hruackom kondicionalom ${ }^{48}$, prenio dometanjem riječi kao pred izričnu rečenicu da je Bog. ${ }^{49} \mathrm{U}$ oba slučaja riječ je o istom prijelaznom glagolu. ${ }^{50}$ Duda je pak posve izmijenio strukturu rečenice, pa kod njega čitamo: gradeći se Bogom. Uz to što je odabrao drugi glagol, uza nj se našao instrumental umjesto nominativa. Ali ključna je razlika među glagolima u tome što se uz prvi, prijelazni pokazivati pojavljuje povratna

46 Primjer je preuzet iz Mihaljević (2011: 71).

47 Istraživači generativističkoga usmjerenja dokazuju da je i u sklopovima u kojima nastupaju elementi tradicionalno nazvani prošircima ili predikatnim imenima riječ o „malim surečenicama" (Mihaljević 1982; Birtić, Brač 2016).

48 Otkako je Reinhart (1993: 299) upozorio na kondicional koji u hrvatskom crkvenoslavenskom jeziku stoji prema latinskom konjunktivu, o tom se prijevodnom postupku izvješćuje u više radova: Mihaljević, Reinhart (2005: 66-67); Mihaljević (2006: 225); Mihaljević (2009: 342); Šimić (2000: 70); Ceković, Sanković, Žagar (2010: 146-147); Mihaljević, Vince (2012: 92); Eterović, Vela (2013: 124 -125) i dr.

49 Ishod je hipotetička načinska rečenica s veznikom kao da; usp. Pranjković (2013: 219).

50 U vezi s glagolom kazati valja ukazati na njegovo dvojno značenje 'reći' i 'pokazati' kako u hrvatskom ckvenoslavenskom tako i u drugim jezicima pa se on ili njegove izvedenice pojavljuju u više poglavlja. Ta povezanost seže u indoeuropsku davninu i razumije se iz pravnih postupaka koji su se sačuvali u kasnijim zapisima: „Na sudu se krivina pokazuje ne samo pokretom nego prije svega govorom. Odatle i glagol kazati znači oboje: pokazivanje i govorenje." (Katičić 1990: 82). 
zamjenica se kao objekt, a drugi, graditi se čini nerazdjeljivu cjelinu s česticom se. O možebitnom razlikovanju stvarne i prividne promjene izražene glagolom i predikatnim imenom bilo je riječi u poglavlju 5.4.

\section{Zaključak}

U tradicionalnoj se gramatici polusponski glagoli suprotstavljaju kopuli (sponi) biti ili se među njima ne pravi razlika. Raščlamba neprelaznih glagola koji s imenskim skupinama čine imenski predikat u hrvatskom crkvenoslavenskom jeziku govori u prilog ljestvičnomu prikazu u kojem ni sam glagol biti nije jedinstven. Uloga „čiste” spone pridržana je samo svevremenskomu prezentu glagola biti, tvorenomu od *es-osnove, posve lišenom leksičkoga značenja. To ga obilježje smješta na dno ljestvice. Finitni oblici potekli iz osnove *bheu- postavljaju događaj u vremenski okvir. Još viši stupanj na ljestvici zauzima inkoativno značenje koje se osim trenutnim prezentom, aoristom i imperativom glagola biti izriče i pasivnim oblicima glagola stvoriti te glagolom vstati, a prevodi se 'postati'. Glagoli s istim korijenom, prěbiti, prěbivati i ostati prenose značenje 'ostati'. Najvećom se obavijesnosti odlikuju glagoli koje prevodimo kao 'biti stvoren', 'praviti se, pretvarati se', 'činiti se, izgledati' ili 'zvati se'. Neki se od njih pojavljuju u više značenjskih skupina.

Predikatna imena dijele se na imenička i pridjevska. Izraz u kojem ěko / kako prethodi imenici međustupanj je u kojem imenica poput pridjeva upućuje na svojstvo, a ne na identitet kao prototipna imenica. Uz glagol sa značenjem 'postati' imenicu osim u nominativu zatječemo u akuzativu iza prijedloga $v b$. Rijetki instrumentali ograničeni su na imenice.

Predikatnomu imenu inačica je spoj imenice i pridjeva s infinitivom ili participom glagola biti, a očekivan je i njegov finitni oblik u izričnoj rečenici. Odabrani primjeri iznose na vidjelo i razlike koje se pripisuju grčkom ili latinskom predlošku. To se ponajprije odnosi na razdiobu glagola biti i stvoriti i na prevagu analitičkoga izričaja nad sintetičkim u tekstovima prevedenima s latinskoga. U oba slučaja prema latinskome stoji glagol stvoriti. Utjecaj narodnoga govora najjasnije se pak očituje u prodiranju instrumentala u imenski predikat. 


\section{Kratice izvora}

Amul - Amulet, 15. st.

BrAc - Akademijin brevijar, 1384. (?)

BrBar - Baromićev brevijar, 1493. god.

BrLab1 - I. ljubljanski brevijar (161a/2), kraj 14. st.

$\mathrm{BrLab}_{2}$ - II. ljubljanski brevijar (163a/2), 15. st.

BrN2 - II. novljanski brevijar, 1495. god.

BrPm - Pašmanski brevijar, druga polovica 14. st., prije 1389. god.

BrVat5 - Vatikanski brevijar Illirico 5, sredina 14. st.

BrVat6 - Vatikanski brevijar Illirico 6, sredina 14. st.

BrVat $_{19}$ - Vatikanski brevijar Vat. Slav. 19, 1465. god.

BrVb1 - I. vrbnički brevijar, 13.-14. st.

BrVb4 - IV. vrbnički brevijar, 14. st.

BrVO - Brevijar Vida Omišljanina, 1396. god.

CAc - Zbornik duhovnoga štiva, kraj 15. st.

CGrš - Grškovićev zbornik, 16. st.

COxf - Oxfordski zbornik, 15. st.

CPar - Pariški zbornik, 1375. god.

CPet - Petrisov zbornik, 1468. god.

CVinod - Vinodolski zbornik, poč. 15. st.

CŽg - Žgombićev zbornik, 16. st.

FgGrš - Grškovićev odlomak apostola, 12. st.

FgHom - Homilija na Blagovijest, 13. st.

FgLab $_{1}$ - Ljubljanski homilijar, 13. st.

MHrv - Hrvojev misal, 1404. god.

MKož - Kožičićev misal, 1531. god.

MVat4 - Vatikanski misal Illirico 4, 14. st.

PsFr - Fraščićev psaltir, 1463. god.

PsLob - Lobkowiczov psaltir, 1359. god.

PsPar - Psaltir pariškoga kodeksa, 14. st.

RegBen - Regula sv. Benedikta, kraj 14. st. 


\section{Literatura}

Badurina Stipčević, Vesna (2016) „The Croatian Glagolitic Bible. The State of the Research", Studi Slavistici, 13, 283-297.

Bauerová, Marta (1963) „Bespredložnyj tvoritel'nyj padež v staroslavjanskom jazyke”, Issledovanija po sintaksisu staroslavjanskogo jazyka, ur. Josef Kurz, Československá akademie věd, Prag, 287-311.

Biblija. Stari i Novi zavjet (1968), ur. Josip Tabak i Jerko Fućak, Stvarnost, Zagreb

Birtić, Matea, Ivana Brač (2016) „Male surečenice uz glagole doživjeti i doživljavati”, Rasprave Instituta za hrvatski jezik i jezikoslovlje, 42/2, 309-331.

Brač, Ivana (2017) „Instrumental u kopulativnim rečenicama”, Fluminensia, 29/1, 29-45.

Ceković, Blanka, Ivana Sanković i Mateo Žagar (2010) „Jezik Misala Hruackoga Šimuna Kožičića Benje: glagolski oblici”, Slovo, 60, 133166.

Damjanović, Stjepan (2005) ${ }^{5}$ Staroslavenski jezik, Hrvatska sveučilišna naklada, Zagreb.

Divković, Mirko (1900) ${ }^{2}$ Latinsko-hrvatski rječnik za škole, Naklada kr. hrvatsko-slavonsko-dalmatinske zemaljske vlade, Zagreb.

Eterović, Ivana, Jozo Vela (2013) „Iz sintakse Kožičićeva Misala hruackoga, Slověne, 2, 118-142.

Florschütz, Josip (1940) ${ }^{4}$ Gramatika hrvatskoga ili srpskoga jezika za srednje i slične škole, Naklada školskih knjiga i tiskanica Banovine Hrvatske, Zagreb.

Gortan, Veljko, Oton Gorski, Pavao Pauš (1954) Latinska gramatika, Školska knjiga, Zagreb.

HCSJ (2014) Hrvatski crkvenoslavenski jezik, prir. Milan Mihaljević, Hrvatska sveučilišna naklada, Staroslavenski institut, Zagreb.

Hrvojev misal (1973) Missale Hervoiae ducis Spalatensis Croato-Glagoliticum, ur. Vjekoslav Štefanić, Mladinska knjiga, Ljubljana, Staroslavenski institut „Svetozar Ritig”, Zagreb, Akademische Druck Verlagsanstalt, Graz.

Ivšić, Stjepan (1970) Slavenska poredbena gramatika, Školska knjiga, Zagreb. 
Jeruzalemska Biblija (1994) Jeruzalemska Biblija. Stari i Novi zavjet $s$ uvodima i bilješkama iz „La Bible de Jérusalem”, ur. Adalbert Rebić, Jerko Fućak i Bonaventura Duda, Kršćanska sadašnjost, Zagreb.

Katičić, Radoslav (1986) Sintaksa hrvatskoga književnog jezika, JAZU, Nakladni zavod Globus, Zagreb.

Katičić, Radoslav (1990) „Praslavenski pravni termini i formule u Vinodolskom zakonu", Slovo, 39-40, 73-85.

Mihaljević, Ana (2018) Sintaksa hrvatskoglagoljskih spomenika prevedenih s latinskoga, doktorska disertacija, Filozofski fakultet Sveučilišta u Zagrebu.

Mihaljević, Milan (1982) Instrumental iza objekta u akuzativu uz glagole smatrati, učiniti, zvati..., Suvremena lingvistika, 23-24, 11-16.

Mihaljević Milan (2009) „Hrvatski crkvenoslavenski jezik”, Povijest hrvatskoga jezika. I. knjiga. Srednji vijek, ur. Ante Bičanić, Croatica, Zagreb, 283-349.

Mihaljević, Milan (2006) „Sintaktička svojstva najstarijih hrvatskoglagoljskim fragmenata", Mnogokratnite prevodi v južnolavjanskoto srednovekovie, ur. Lora Taseva, Roland Marti i Marija Jovčeva, GorexPress, Sofija, 2006, 221-239.

Mihaljević, Milan (2011a) "Verba dicendi in Croatian Church Slavonic”, Zbornik Matice srpske za filologiju i lingvistiku, 54/1, 63 -77.

Mihaljević, Milan (2011b) „Dopune percepcijskih glagola u hrvatskome crkvenoslavenskom jeziku", Suvremena lingvistika, 54/1, 187-200.

Mihaljević, Milan (2018) „Sintaktička istraživanja hrvatskoglagoljskih tekstova: stanje i perspektive", Visnyk L'vivs'kogo univesitetu. Serija filologična, 69, 66-74.

Mihaljević, Milan, Johannes Reinhart (2005) „The Croatian Redaction: Language and Literature", Incontri Linguistici, 28, 31-82.

Mihaljević, Milan, Jasna Vince (2012) Jezik hrvatskoglagoljskih Pazinskih fragmenata, Hrvatska sveučilišna naklada, Državni arhiv u Pazinu, Staroslavenski institut, Zagreb.

Misal hruacki (2016) Misal hruacki Šimuna Kožičića Benje. Latinička transliteracija glagoljskog izvornika s usporedbom jezičnih oblika prema drugim glagoljskim tiskanim misalima XV. i XVI. stoljeća, prir. Blanka Ceković, Ivana Eterović, Tanja Kuštović i Mateo Žagar, Nacionalna i sveučilišna knjižnica Zagreb, Sveučilišna knjižnica Rijeka. 
Pantelić, Marija (1973) „Hrvatskoglagoljski amulet tipa Sisin i Mihael”, Slovo, 23, 161-203.

Pavešić, Slavko, Zlatko Vince (1971) „Gramatika”, Jezični savjetnik s gramatikom, ur. Slavko Pavešić, Matica hrvatska, Zagreb, 331-446.

Peti, Mirko (1979) Predikatni proširak, Hrvatsko filološko društvo, Zagreb.

Požar, Sandra (2017) „Stupanj popridjevljenosti participa i njegov odraz u leksikografiji: primjer pasivnih preteritnih participa s prefiksom neiz korpusa Drugoga beramskoga brevijara", Filologija, 69, 61-82.

Pranjković, Ivo (2013) Gramatička značenja, Matica hrvatska, Zagreb.

RCJHR (2000) Rječnik crkvenoslavenskoga jezika hrvatske redakcije, I. svezak, Staroslavenski institut, Zagreb.

RCJHR (2015) Rječnik crkvenoslavenskoga jezika hrvatske redakcije, II. svezak, Staroslavenski institut, Zagreb.

Reinhart, Johannes (1993) Untersuchungen zur Syntax des Kroatisch-Kirchenslavischen: Das Glagolitische Missale romanum, Habilitationsschrift zur Erlangung der Lehrbefugnis an der Univetsität Wien.

Senc, Stjepan (1910) Grčko-hrvatski rječnik za škole, Naklada kr. hrvatskoslavonsko-dalmatinske zemaljske vlade, Zagreb.

Silić, Josip, Ivo Pranjković (2005) Gramatika hrvatskoga jezika za gimnazije i visoka učilišta, Školska knjiga, Zagreb.

Stolac, Diana, Anastazija Vlastelić (2017) „Metodološki izazovi suvremenih istraživanja povijesne sintakse hrvatskoga jezika”, Definitely perfect. Festschrift for Janneke Kalsbeek, ur. René Genis, Eric de Haard i Radovan Lučić, Uitgeverij Pegasus, Amsterdam, 641-658.

Sveto pismo Staroga i Novoga zavjeta (1912), preveo Stari zavjet Gj. Daničić, Novi zavjet preveo Vuk Stef. Karadžić, izdanje Britanskoga i inostranoga biblijskoga društva, Budimpešta.

Šimić, Marinka (2000) „Jezik Muke po Mateju u hrvatskoglagoljskim misalima", Slovo, 50, 5-117.

Večerka, Radoslav (1993) Altkirchenslavische (Altbulgarische) Syntax. II: Die innere Satzstruktur, U. W. Weiher, Freiburg i. Br.

Vela, Jozo (2018). Sintaksa infinitiva i supina u hrvatskome crkvenoslavenskome jeziku, doktorska disertacija, Filozofski fakultet Sveučilišta u Rijeci. 
Vince, Jasna (2010) „Nominativ prema ostalim padežima”, Sintaksa padeža. Zbornik radova znanstvenoga skupa s međunarodnim sudjelovanjem „Drugi hrvatski sintaktički dani (Osijek, 13. - 15. studenoga 2008.)”, ur. Matea Birtić i Dunja Brozović Rončević, Institut za hrvatski jezik i jezikoslovlje , Filozofski fakultet Osijek, Zagreb, 249-265.

Vince, Jasna (2017) „Primjeri poimeničenja u Rječniku crkvenoslavenskoga jezika hrvatske redakcije", Filologija, 69, 175-203.

Vince, Zlatko (1978) Putovima hrvatskoga književnog jezika. Lingvističkokulturnopovijesni prikaz filoloških škola $i$ njihovih izvora, Sveučilišna naklada Liber, Zagreb.

Vince Marinac, Jasna (2001) „Predikatni instrumental i njegove inačice u hrvatskom crkvenoslavenskom i starohrvatskom jeziku", Drugi hrvatski slavistički kongres. Zbornik radova I., ur. Dubravka Sesar, Ivana Vidović Bolt, Zagreb, 283-289.

The Scholarly Bible Portal of the German Bible Society, <https://www. academic-bible.com/en/online-bibles/septuagint-lxx/read-the-bibletext/>

\section{SUMMARY \\ Jasna Vince \\ NOMINAL PREDICATE WITH TRANSITIVE VERBS IN CROATIAN GLAGOLITIC TEXTS}

The paper is dedicated to transitive verbs and nominal phrases forming nominal predicates in Croatian Glagolitic texts. Only the present tense forms from the ${ }^{*} e$-stem are considered to constitute „pure” copula with no lexical meaning. The finite forms originating from the *bhu-stem put the narrated event into the time frame. A large group of semi copular verbs with the meaning 'to stay', 'to be made, 'to become', 'to pretend', 'to seem, to look like' and 'to be called' are further discussed. The author points to the influence of Greek and Latin written sources as well as vernacular on Croatian Church Slavonic syntactic constructions.

Key words: Croatian Church Slavonic; nominal predicate; copular and semi copular verbs; predicative nominal; Latin and Greek written sources 